\title{
Borders and the Limits of Authority
}

\author{
Robert M. Hayden \\ University of Pittsburgh
}

\begin{abstract}
In this article I introduce a variety of social, political and economic collectivities to analyze ways in which their interactions are influenced by borders as the territorial delimitations of legal authority, or jurisdictions. The limits of authority within such collectivities are seen in the overlapping grants of authority that impact them. To the extent that borders delineate spheres of legitimate action by governments, they can be defensive of the rights of people within them as well as protective of the rights of governments to impinge on those same rights, or both simultaneously. Borders can thus be constraining of those who cannot easily pass across them, yet simultaneously unconstraining of international actors who may be predatory on those who expect their state to protect them. If we are to understand borders, boundaries and cognate phenomena, we need always to take both sets of relations into account.
\end{abstract}

Key-words: Borders, Jurisdiction, Non-territorialized authority, Europe, India.

Borders are perhaps first and most often seen as the territorial delimitations of states, and their characteristics as varying. Such borders can be largely innocuous, possibly even without controls, as within the Schengen Zone of the European Union, or between Ireland and the UK in Northern Ireland before Brexit, or between states in the USA or provinces within Canada. In the former Yugoslavia, for instance, the borders between republics were not even marked in any obvious fashion, unlike those of the American states, where one is always welcomed to that state by the current governor.

Less innocuous, and unavoidably noticeable, are borders that do have controls. Coming to Greek beaches from Belgrade each summer, for example, usually costs me at least a few hours waiting to cross checkpoints, and a couple of pages of my passport, since I get stamped for the exit from Serbia, entry into North Macedonia, exit from North Macedonia, entry to Greece, and the reverse on the way back. This is clearly a nuisance for tourists and other temporary leisure seekers, like my family and me, but it is much worse for lorry drivers, who can wait far longer than we do, with costs rising with each minute spent waiting in the queue.

But this kind of controlled border - within and beyond southeastern Europe - is only a nuisance for those who have travel documents, visas if needed, money and transportation. 
For people without some or even all of those attributes, controlled borders are dangerous obstructions, marked by hostile officials, guards, razor wire, dogs and sensors. In the United States, from mid-June 2018 to the end of the Trump administration, the government's policy was to separate children, even very young children, from their parents - a policy so cruel as to make further comment impossible. But even without such policies, observers of the migrants into Europe from the Middle East and North Africa know that there many unaccompanied children on those pathways.

It is these kinds of negative consequences of borders - the costs and nuisance factors at best, and dangers and hardships at worst - that set most of our images of how borders function: as obstructions to ordinary forms of social life, and worse than that in cases of extreme hardship. And perhaps because some people in many countries believe that borders serve mainly to provide security from outside threats, obstructions at borders are gaining in visibility and, frankly, brutality. The border between Serbia and Hungary that migrants simply walked across in 2015 was by 2016 militarized and multiply fenced. Arguably, after the 'migration crisis' the EU Curtain imposed on southern parts of Europe to protect more northern reaches is as formidable as was the Iron Curtain that kept Hungarians and other East Europeans from going into western parts of Europe from 1945-89.

We are thus so used to linking borders with states and increasing government repression that it might be difficult to envision a different context. But I think that the crisis-driven focus on governments and their control over entry into states diverts us from seeing borders, border-making and border communities in their full range. As Didier Fassin has reminded us (2011, 214-15), there was an early practice in social science of distinguishing between borders as the territorial demarcations between states, and boundaries as labels for symbolic differences between social groups (e.g. tribes, caste, nations, genders). In this article, I want to pursue this idea further, and look at some ways in which the demarcation of territories is carried out by social groups communities - that are below the level of the state, yet have great importance on social life and, at times, also on how states themselves are able to operate. Before focusing on further remarks, I will start by drawing an example from some fieldwork I did in India, as a doctoral student, in order to bring out some issues surrounding territories, borders and communities.

In the mid-1970s, I conducted research in the middle of a western Indian countryside, fifty kilometers from the village of Wadapuri, Indapur Taluka, Pune District, Maharashtra. I was fortunate enough to be included in a field school being supervised by an Indian anthropologist studying a group of nomads, who can be called the Bull People (Nandiwallas). This is the name of their caste, and their traditional occupation was to wander from village to village with trained bulls. In rural India at that time, with no television, little radio and films not easily seen outside of cities, this was a primary form of entertainment - these people had trained bulls, and there were other such nomadic castes with trained bears, or performers with leather puppets, or folk medicine practitioners, or travelling genealogists, and other entertainment and service occupations (see Hayden 1979). 
Like most nomads, the Nandiwallas were largely outside of the control of the state, or at least as much outside of it as they could be. Everywhere in the world, nomads' experiences with police are rarely happy ones. These people were also all illiterate. They carried everything they owned on their animals and lived in tents. They benefitted indirectly from state programs like the control of smallpox, etc., and they used cash money (rupees) issued by the Indian state. But other than that, they kept as much as possible to their own affairs, and avoided police and courts unless the former hauled them before the latter. They moved through parts of several south Indian states, but the state borders meant little to them, other than maybe a change in the local language; but since they spoke the relevant languages, that did not matter.

This Indian case raises interesting issues for consideration in European and wider contexts. For the Bull People, while borders per se were not important, territories were. Even though they were nomads, they were very territorial. Each family had its own vatan (an Arabic word also found in Turkish - homeland, territory - and thence into Bosnian/ Croatian/ Serbian), its own territory with villages where only the members of that family were permitted to go. Their explanation was simple and logical - there just was not enough interest in bull performers (or performers with trained bears, or leather puppets, or genealogists) to support more than one family going through per year.

But sometimes people did go to vatans that were not their own. When that happened, the family whose territory had been visited did not go to state courts - they could not do so. Instead, they took the matter to the council of the caste (as it happens, the topic of my dissertation), which inevitably fined the trespasser (Hayden 1999a). But a question that arose in my research, in response to this situation, was a simple one: why did the miscreants pay? The caste had no police of its own, or jails. So why would someone who trespassed pay a fine?

The answer to that was simple, too. In rural India at the time (and still in many cases), your primary identity was closely tied to your caste - and marriage was only permitted within the caste. If you defied the caste, the other caste members would not help you and - crucially - no one would marry your children. So defying the caste meant profound social and economic isolation, and ultimately threatened the ability to carry on with reproducing your family - literally. Thus everybody paid, and I saw disputes, up to and even murder cases, being resolved this way.

This case suggests a couple of important points for considering borders, boundaries, territory and community. With the Bull People, marked territory (borders) were linked to social groups (families), but at levels below those usually used for analysis. The borders in question were not only not between states, but were those which states were not aware of. And the social groups involved were extended families, not rising to the level even of lineage or clan - though they were contained within the one caste of Bull People. What makes the borders real was in fact their relevance to that community, the caste of Bull People.

This case also suggests focuses that are not as apparent in the comparative study of borders and border crossings as they might or should be. In southeastern Europe, for example, state borders will obviously be relevant in countries such as Albania, Greece and North Macedonia (the former FYR Macedonia). But territorial and other geopolitical borders within each of these countries may 
also be tied to the boundaries of various communities, defined by primary categories of group identification, such as nation, state membership (citizenship), language, and religion. Within those primary categories there is a range of others needing ethnographic attention: gender, class, occupation, and, within religion, differences between Christians (Greek Orthodox, Macedonian Orthodox, Albanian Orthodox, Roman Catholic, Protestant), Muslims (Sunni, Shi'a, Alevi/ Bektaši and other dervish orders - Bayrami, Mevlevi, Nekšibandi, et al.), and Jews, to say nothing of atheists and agnostics. State boundaries are obviously relevant for all of these categories of identification and analysis, but the point of my story about the Bull People is that ethnographers must also be aware of and look for the communities that the State may not care about very much, and their territories/ borders as well. In addition, ethnographers should also pay attention to the supra-state levels of communities, or claims to be communities, that operate across state borders, and how those influence activities at sub-state levels of community.

Note that I say 'primary categories' because the idea that all aspects of one's potential identities are of equal salience is untenable. While the concept of intersectionality recognizes this fact in part, it is less clear on how the varying cultural categorizations of potential identity markers are ranked. In this regard, recent references to Louis Dumont's concept of hierarchy may be useful (Houseman 2015; Robbins and Siikala 2014). The integration of elements of a system manifests subordination of some to others that incorporate them, thus forming a whole, but composed of unequal components. Thus in some situations someone is rarely simply a female, for example, but rather a Greek, Albanian or Macedonian female, etc. Some classifications might be relevant only within a larger classification. For example, non-Muslim Bulgarians seem largely unaware of the distinctions among Muslims in Bulgaria between adherents of Sunni Islam and followers of orders such as the Bektašis, though Sunnis and Bektašis are well aware of their differences (Sözer 2014).

\section{Territorial Jurisdiction, Demos, Democracy}

Present-day images of borders rest on a profoundly modern concept: the state, comprised of a territory and a population subject to an organized political authority. Both parts of this definition are crucial. The state has a well-defined territory in which the organized political authority is the sole legitimate governing power. The authority of a government to enact and enforce laws - its jurisdiction - is thus limited to the specific territory of the modern state. Crucially, each state has the exclusive power to govern within own its territory - exclusive in the sense that no other state may legitimately claim authority to do so.

There is a strong link between this concept of the state as territorially delimited and modernity (Galanter 1966). Crucially, there is also a strong link between this concept and that of democracy, rule by the demos, or common people, as opposed to royalty and aristocracy. If the King is sovereign in a system of royal or imperial rule, it is the people who are sovereign in a democracy. But this raises the question of which people? Usually, the modern answer to that question, at least from an American perspective, is that it is the entire population, though that is not an idea with 
much widespread salience in the modern European history. In many circumstances, the general construction of nation-state in Europe meant that the nation (narod, das Volk), a heritage-defined group, is sovereign by having its own state (država, Staat), its own territory plus government (Hayden 1992). This leaves minorities in, generally, an inferior position, even when citizens; the phrase that we sometimes see, of "human and minority rights" is open to a bit of a disquieting interpretation, that "minorities" are not quite the same as "humans" - with the politics of majoritarianism based on the rather bizarre assertion that minorities are given too much.

In any event, though, the link between territorial jurisdiction and demos does have a fairly strong logic, which becomes clear when one extends voting rights to non-territorial members of the demos. This can put the fate of people within the territorial borders of the state at the mercy of those who do not live there, as apparently happened in the Turkish election of June 24, 2018 - the $50 \%$ of the population living within Turkey that does not want the one-man rule of Erdoğan is still subjected to it because of the heavy émigré vote for him. Further, the alternative is not necessarily desirable, in that in most places, people whose primary loyalty is said to be to another state will be under suspicion of disloyalty to the place where they actually live. In both cases, there is a conflict between the territorial delimitation of the state by borders, and the non-territorial boundaries of nations.

\section{Non-territorial Jurisdiction}

\section{Human Groups: Religious Communities and Nations}

The condition of asserting non-territorial jurisdiction is also problematic, though it has been common. In monarchical systems, one is a subject of the monarch, rather than a citizen, so the monarch can claim loyalty of subjects not within her/his territory. One can see non-territorial jurisdiction in religious communities, which can have their own legal systems. Some religious courts are recognized by states. Thus, and oddly enough, Greece is the last European state to give official status to the successors of the sharia courts of the Ottoman Empire, due to provisions of the Treaty of Lausanne in 1923, which still bind Greece even though Turkey abolished sharia courts in 1926. The Austro-Hungarian Empire had recognized sharia courts in Bosnia from 18781919; then the Kingdom of Yugoslavia did as well, 1920-45, when they were abolished by the Communist regime (Greble 2014). Other religious courts are not recognized by states but may be seen as binding by members of that religion. For example, many divorced Roman Catholics who want to marry a second time use ecclesiastical courts to obtain a religious annulment of the marriage that has already been dissolved by state action. The religious decree is not recognized by any state, but without it the person cannot both remarry and remain a Roman Catholic in good standing with the Church. This process costs time and money to remain part of the group, a situation that actually has a lot in common with that of the Bull People who pay the price of readmission to good standing in the caste. 
In the Balkans, religious communities have complex relationships with nations and states, and thus with borders. While presumably a person of any religion, or none at all, can be a citizen of Greece, whether someone who is not of Greek Orthodox Christian heritage is a member of the Greek nation is another question, at least for some parts of the population. There are, of course, Muslim citizens of Greece - some of whom may make use of the sharia courts noted above - but neither they nor most Greeks regard themselves as ethnic Greeks. They may instead be called/ call themselves Turks or Pomaks/Bulgarian-speaking Muslims.

Among Macedonians this is even more complicated because the Serbian Orthodox Church has long had ecclesiastical jurisdiction over Macedonia - though that is now challenged by the Macedonian Orthodox Church. But the proclamation of that Church is a result of the establishment of Northern Macedonia as an independent state, which means that the identity of the religious community is determined by the presence of a state.

The preceding discussion has moved quickly from borders (of states) to boundaries (of communities) and back again, because these phenomena do not necessarily coincide. When they do not, accommodations may be sought - e.g. the recognition by the Greek state of sharia courts for Turks. But then again, the accommodation may be more symbolic than real. About a decade ago, the Greek state was having legal issues concerning the state's insistence on appointing sharia judges, instead of letting the community do so. In any event, recent legislation is aimed at ending mandatory sharia jurisdiction in family law cases involving Turks. This move seems in part due to a desire to avoid problems with the European Court of Human Rights.

But the shift is also due to the close connection between religious heritage and national identity among most of the peoples of the Balkans (and not only there), and the less than consistent ways in which the borders of state do not coincide with the boundaries of nations. For example, in the summer of 2000, I had an interesting discussion in Skopje with some ethnic Albanians who worked in the city administration. They asked me to explain convincingly why they should be willing to recognize a border between Macedonia and Kosovo, which had been created with the declaration of Macedonian independence in 1992. They all had family in Kosovo, some were themselves from there, and had been educated there. For the preceding 600 years, there had not been a border there, the entire territory having gone from being Ottoman to being Serbian to being Yugoslav, except for a couple of very brief periods of Bulgarian occupation of Macedonia in 191516 and 1941-45. There were also large ethnic Albanian populations on both sides of the newly proclaimed border.

One could answer - and I did answer - that however artificial a specific border might seem, it would not be possible to draw any other one that would be less so, and that the international system for the past two centuries has depended for stability on the principle that borders define states, which are sovereign. In this case, once it had been accepted by the international community that the republics composing Yugoslavia could declare themselves to be independent, borders could not be changed, and people suddenly transformed from equal citizens of the socialist state (in which sovereignty belonged to the working class and all working people) would have to accept being minorities in states in which sovereignty would now be defined as resting with the majority 
nation (narod). Promises that the rights of these minorities would be protected were not very convincing, and in fact in most cases their rights have not been well protected. But then, the Minorities Treaties of the League of Nations had also not worked out well for the people supposed to be protected by them (Macartney 1934).

\section{Corporate groups: Corporations and NGOs}

Nations and religious communities are collectivities of people believed to be bound by heritage and belief. A rather different kind of collectivity would be a corporate actor. Corporations are interesting anthropologically because even major international ones known for the standardization of their products inevitably wind up modifying them to fit local tastes and economic conditions. The classic study is Woody Watson's Golden Arches East (Watson 1997), showing how MacDonald's offerings differ in various east Asian countries, as they do elsewhere, and The Economist magazine of London has long used the Big Mac Index - the varying prices of a Big Mac as measured against the British pound or the US dollar, as a way of estimating price differentials between states. If one wants to really see corporate flexibility in action, check out McDonald's offerings in India, where the open sale of beef is prohibited in many states and many people are vegetarians. No matter how powerful the corporation, its success will depend on how well its products and services are received locally.

Nongovernmental Organizations (NGOs), on the other hand, seem largely immune to local preferences, since each generally advocates an ideology that is said to be universal, and demands that local communities alter their practices to accept it. They also claim superiority to mere state governments. The name of the organization Médecins Sans Frontières/Doctors without Borders says quite a lot, as does their statement of principles. MSF "claims full and unhindered freedom in the exercise of its functions", which are to "provide assistance to populations in distress, to victims of natural or man-made disasters and to victims of armed conflict ... in the name of universal medical ethics and the right to humanitarian assistance." (MSF, n.d.)

"Unhindered" by borders means unhindered by state authorities. MSF claims a right to be able to act in accordance with its own assessments of what is needed, without hindrance by governments, and also without accountability to them, or to anybody else: "We assume the responsibility of accounting for our actions to our patients and donors" (MSF, n.d.). This is a really strikingly arrogant position, by foreigners claiming the right to determine what is in the interest of people with whom they otherwise have no connection, a right they subordinate to the interests of their funders. Please do not misunderstand me - I think MSF has done great work in a lot of places. What I want to stress is the idea that borders are a hindrance, because they demarcate territories under the control of governments, while MSF claims to be superior to any such authority. They are not the only organization to make such a claim. Human rights organizations also claim to uphold morality superior to that of political authorities. Whether they actually do so is a point that might sometimes be contested, although many NGOs now routinely hide their sources of funding and the like, so holding them accountable is quite hard. But that is a topic for another time. Still, 
if the point of democracy was to enable the demos to govern themselves, the assertions of supranational authority by NGOs are anti-democratic.

And perhaps more than that. Immediately after the NATO war against Serbia over Kosovo, Human Rights Watch (HRW) proudly stated that the erosion of state sovereignty by human rights meant that human rights organizations could "move from a paradigm of pressure based on international human rights law to one of law enforcement" via military intervention (see Hayden 2000, 549-550). Considering that almost all of the NATO bombing of Serbia was against civilian targets, an NGO claiming to have the right to compel military attacks against civilian populations should be alarming (see Hayden 1999b). Indeed, a U.S. human rights activist turned neocon justified the American invasion and occupation of Iraq on the grounds of enforcing human rights (Cushman 2005). That this author's murky crystal ball did not foresee that the invasion and occupation of Iraq, and the subsequent insurgency, would lead to some 450,000 casualties (Hagopian et al. 2013) is surely regrettable. Perhaps human rights omelets also require breaking eggs. But the point is that the post-1945 international legal norm prohibiting interstate aggression had sound reasoning behind the approval of the rigidification of state borders.

\section{Intergovernmental Organizations}

The states of the Balkans differ in their involvement with the European Union and its attendant bureaucracies. Only Greece is a EU member state, yet all of the Balkans states, whether EU members or not, are largely subordinated to EU regulations of varying kinds. One need only look at the varieties of fruits and vegetables in their markets, since throughout Europe, local varieties have largely been displaced by hybrids that meet various EU standards. The large numbers of imported produce in all of the European states also speaks of a profound overcoming of borders in the name of commerce: goods move internationally. Money, on the other hand, is another issue. Few after 2015 would deny that the adoption of the euro as a currency had devastating results on the Greek economy, so that Macedonians and Albanians may be better off with the denar and lek than they would be if their currency was the euro - provided, of course, that they also have access to euros. The European Central Bank, the World Bank and the IMF have enormous control over how people live; and the Greek crisis of 2015 made it crystal clear that as far as the bankers are concerned, Greek democracy (and the well-being of the population of Greece) were irrelevant.

\section{Delineating Authorities}

I have briefly introduced a wide variety of social, political and economic collectivities to turn attention to the ways in which their interactions are influenced by borders as the territorial delimitations of legal authority, or jurisdictions. Note that I say 'influenced by', not 'determined by'. The limits of authority within such collectivities are seen in the overlapping grants of authority that impact them. To the extent that borders delineate spheres of legitimate action by governments, 
they can be defensive of the rights of people within them as well as protective of the rights of governments to impinge on those same rights. Or both simultaneously, as Heath Cabot has shown in her studies of the ways that "the replacement of both social rights (afforded to citizens) and human rights (afforded to refugees) with humanitarian logics and sentiments, position[s] both citizens and non-citizens in a partially shared continuum of precarity" (Cabot 2018). Borders can thus be constraining of those who cannot easily pass across them, yet simultaneously unconstraining of some kinds of international actors who are predatory on those who expect their state to protect them. If we are to understand borders, boundaries and cognate phenomena, we need always to take both sets of relations into account.

\section{Notes}

${ }^{1}$ This article stems from the keynote lecture presented in July 2018 at the 13th Konitsa Summer School in Anthropology, Ethnography and Comparative Folklore of the Balkans, Greece, cosponsored by the Border Crossings Network. I would like to thank the organizers, especially Dr. Aliki Angelidou and Dr. Ioannis Manos, other participants and students, for their hospitality, collegiality and comments, formal and informal. I would also like to thank Tom Wilson and Davide Carnevale for their comments and editorial work in helping turn what had been a lecture into an article. 


\section{References}

Cabot, Heath. 2018. "The European Refugee Crisis and Humanitarian Citizenship in Greece." Ethnos 84: 1-25.

Cushman, Thomas, ed. 2005. A Matter of Principle: Humanitarian Arguments for War in Iraq. Berkeley: University of California Press.

Fassin, Didier. 2011. "Policing Borders, Producing Boundaries: The Governmentality of Immigration in Dark Times." Annual Review of Anthropology 40: 213-226.

Galanter, Marc. 1966. “The Modernization of Law.” In Modernization, edited by Myron Weiner, 153-165. New York: Basic Books.

Greble, Emily. 2014. "Illusions of Justice: Fascist, Customary and Islamic Law in the Independent State of Croatia." Past \& Present 224, no. 1: 249-274.

Hagopian, Amy, Abraham D. Flaxman, Tim K. Takaro, Sahar A. Esa Al Shatari, Julie Rajaratnam, Stan Becker, Alison Levin-Rector et al. 2013. "Mortality in Iraq Associated with the 20032011 War and Occupation: Findings from a National Cluster Sample Survey by the University Collaborative Iraq Mortality Study." PLOS Medicine 10, no. 10 (October).

Hayden, Robert M. 1979. "The Cultural Ecology of Service Nomads.” Eastern Anthropologist 32: 297-309.

Hayden, Robert M. 1992. "Constitutional Nationalism in the Formerly Yugoslav Republics." Slavic Review 51, no. 4: 654-673.

Hayden, Robert M. 1999a. Disputes and Arguments in a Nomad Caste Council. Delhi: Oxford University Press.

Hayden, Robert M. 1999b. "Humanitarian Hypocrisy." East European Constitutional Review 8, no.3: 91-96.

Hayden, Robert M. 2000. "Biased 'Justice': Humanrightsism and the International Criminal Tribunal for the former Yugoslavia." Cleveland State Law Review 47: 549-573.

Houseman, Michael. 2015. "The Hierarchical Relation: A Particular Ideology or a General Model?" HAU: Journal of Ethnographic Theory 5, no. 1: 251-269.

Macartney, Carlile Aylmer. 1934. National States and National Minorities. Oxford: Oxford University Press.

MSF. n.d. "The MSF Charter.” Accessed June 20, 2021. www.msf.org/msf-charter.

Robbins, Joel, and Siikala, Jukka. 2014. "Hierarchy and Hybridity: Toward a Dumontian Approach to Contemporary Cultural Change." Anthropological Theory 14, no. 2: 121-32.

Sözer, Hande. 2014. Managing Invisibility: Dissimulation and Identity Maintenance among Alevi Bulgarian Turks. Leiden: Brill.

Watson, James L., ed. 1997. Golden Arches East: McDonald's in East Asia. Palo Alto: Stanford University Press. 